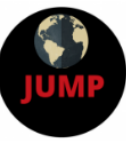

ISSN: 2574-3465 Print/ ISSN: 2574-3481 Online

Volume 1, Issue 1 (2017), pp. 36-51

(C) Journal of Underrepresented and Minority Progress

http://minorityprogress.org/

doi: 10.5281/zenodo.1165452

\title{
Call for Institutional Action: Bridging the Gap Between Access and Persistence in Higher Education in the Caribbean
}

\author{
Saran Stewart \\ Nicola Paterson \\ Shenhaye Ferguson \\ University of the West Indies, Mona, Jamaica
}

\begin{abstract}
Currently, Caribbean higher education institutions benefit from relatively high retention rates among students, however they have seen a rise in low on-time, graduation rates. Given this context, this study applies Tinto's theoretical framework (1975) for understanding and identifying the causes of low student retention and graduation rates at a regional university in Jamaica. Within a United States context, this institution would be considered a predominantly minority-serving institution such as historically black colleges and universities (HBCU) given its large population of Black students. Analysing data from the university's Student Experience Survey, the results indicate that, academic performance and financial issues were leading factors to non-returning students and low graduation rates. The findings reflect that full-time status is the strongest predictor of GPA and on-time graduation. To bridge the gap between access and persistence, we suggest strategies to improve issues of inequities and academic engagement at both the individual and institutional level.
\end{abstract}

Keywords: access, Caribbean, persistence, student retention, undergraduate

Globally, student retention and persistence have been shaped by various theoretical frameworks for the assessment of higher education. In the United States, student retention has emerged for gauging the effectiveness of higher education institutions and the relative performance of students enrolled in these institutions. The likelihood of a student persisting or not persisting in higher education has been examined using theories of academic and social integration (Tinto \& Cullen, 1973; Tinto, 1975), pedagogy (Tinto, 1999, 2013), level of institutional support (Tinto, 2004, 2006), and the level of student involvement (Astin, 1999). Within the Caribbean, assessment of higher education has typically reflected a Quality Management System (QMS) approach or 'fitness for purpose' model that is linked to institutional effectiveness within a strategic planning framework (Gift, Moniquette \& Perkins, 2010). The social and economic context of the Caribbean has given rise to concerns about access (Grant-Woodham, 2007; Hamilton \& Severin, 2005), financing (Davies, 2005; Hutton, 2010; James \& Collins, 2005; Shaw, 2005), gender participation (Bastick, 2002; Chipman-Johnson \& Vanderpool, 2003; 
Reddock, 2010), internationalization (Black, 2015; Wint, 2010), and the labour market (Hutton, 2009; Morris, 2009) in tertiary or higher education.

While research exists on quality issues in tertiary education in the Caribbean (Alleyne, 2015; Gift, Moniquette \& Perkins, 2010; Leo-Rhynie, 2005; Roberts, 2007), much of this research is focused on the effects of liberalization and increased competition or an overview of the accreditation process. A few studies have been published (Down, 2010; Edwards-Henry, 2015; Gift, 2015; Paterson \& Stewart, 2016) which address assessment and student retention in higher education as it relates to the theory and praxis of teaching, learning and student development and the need to re-think current conceptions and practices.

Given the context of higher education in the Caribbean, and the need to rethink current conceptions and practices, this study will discuss the merits of Tinto's theoretical framework (1975) for understanding student retention and graduation at a regional university in Jamaica.

The study has two main aims: 1) to examine the extent to which individual and institutional characteristics impact student retention and graduation rates; and 2) to develop a model of access and retention programs. Although Tinto's (1975) theory is a widely known and tested theory within the field of higher education and student affairs, this study is unique in that Tinto's framework has not been applied and studied within the Caribbean context. The results from the data analysis also provide a longitudinal framework for examining student outcomes five years after the initial study. Whereas retention is the focus of Tinto's theory, this study adds to the existing theory by examining the graduation rates of students and puts into perspective the factors influencing students who have taken leave, withdrawn, transferred, or dropped out of the University by December 2015.

\section{LITERATURE REVIEW}

Tinto's body of work has contributed greatly to understanding the various demographic, social, psychological, and institutional factors on student retention and drop out. Commencing with his seminal study on Dropout from Higher Education (Tinto \& Cullen, 1973; Tinto, 1975), Tinto outlines a theoretical model for understanding a student's decision to stay or withdraw from college.

The theory takes its roots in Durkheim's theory of suicide where an individual's decision to drop out is the result of 'insufficient regulation of the individual ... during time[s] of significant social upheaval' (Tinto, 1975, p. 91). A university or college is a microcosm of society and replicates the experiences of socialization and integration. Tinto argued that the degree to which students are academically and socially integrated into a university are mediated by the individual's personal commitment to their studies and the institution, and the institution's commitment to students by providing sufficient supportive mechanisms to meet the needs of students.

In terms of operationalizing these processes for the purpose of prediction, an institutional study would include measures related to family background, individual attributes, and precollege schooling on personal and institutional commitment. Other measures are environmental variables such as the grade performance and intellectual development of the students as indicators of academic integration, and peer-group interactions and faculty interactions as indicators of social integration (institutional responsiveness). Tinto warned, however, that understanding the motivations of students was key to elaborating on the nature of departure as the decision to leave could be understood as temporary leave, transfer, voluntary withdrawal, and academic dismissal. Given these distinctions in student departure, Tinto advised that the decision to leave should be 
related to the interests and goal commitments of students and that higher education institutions should not attempt to serve, in an uncritical manner, each person who enters.

A few years later, Tinto's body of scholarship focused on the institution's role in developing and retaining students. According to Tinto (1999), while students' attributes are largely beyond the control of institutions, institutions can control the settings in which students find themselves such as classrooms and laboratories. To the extent that learning is active and engaging for students, the greater the likelihood of students remaining in college. However, Robinson (2004) argued that institutions could go a step further, by utilizing the pathway approach which was applied to higher education in Australia, whereby the institution tracks students' progress on a year to year basis for example, to identify common patterns to gather data that would inform programs and policies implemented to ensure students are retained and complete their degrees.

Staying within the limits of institutional action on retention, Tinto's recent works (2004, 2006) have called for more action to address the lower retention and graduation rates of lowincome and academically under-prepared students. Proposed interventions include adequate financial aid to support full-time, rather than part-time study, and sufficient advising, counselling and mentoring support services (Tinto, 2004).

In addition to addressing these inequalities in higher education, Tinto calls for more resources to be placed on teaching excellence to encourage academic staff to take retention seriously. Tinto (2006) highlights the fact that the faculty of universities and colleges are the only faculty not trained to teach their students. Faculty are also not likely to take retention seriously if the reward system values research and funding over teaching excellence.

Despite the volume of literature that has been produced about student retention, Tinto (2006) warns that the theoretical insights do not tell practitioners what they should do to achieve, for example, academic and/or social integration in their setting. What is therefore needed is a model of institutional action that provides guidelines for the development of effective policies and programs to improve student persistence. However, Rovai (2003) states that Tinto's model has limited applicability for studying the attrition of older students who are less likely to be influenced by academic and social integration as his model focuses on the persistence of traditional undergraduate students.

Gale and Parker (2014), focused on universities in transition, and argued that one should not only focus on transition for first year students but also to address issues prior to entry to higher education as well as the latter years of undergraduate and postgraduate studies. They support the call for institutional action in alleviating high students' retention rates by creating avenues that will "bring new insights into how student transition is experienced, conceived and addressed" (Gale \& Parker, 2014, p. 31). Gale and Parker (2014) support the notion that institutional action does impact students' retention rate as without guidance on how to navigate the university space some students will face challenges of completing degree within the stipulated period which is highlighted in the findings of this study.

As such, Tinto (2006) says the area is ripe for studies that examine, for example, the impact of faculty development programs on student learning and persistence; the use of varying curricular, pedagogical, grading and assessment practices on student learning and persistence; and the use of adjuncts and junior faculty in large, first year classes on student learning and persistence. According to Braxton, Milem and Sullivan (2000), the likelihood of student persistence being greater in colleges is heavily dependent on the level of institutional commitment. 
Another influential theory that emerged about student retention is the theory of student involvement as advanced by Alexander Astin (1999). By involvement, Astin referred to the behavioural component of student activity. "It is not so much what the individual thinks or feels, but what the individual does ... that defines and identifies involvement" (Astin, 1999, p. 519). In contrast to Tinto's focus on motivation, Astin puts the spotlight on action.

The theory of student involvement sees time as a precious institutional resource. The extent to which students can achieve developmental goals is a direct function of the time and effort they spend on learning activities (Astin, 1999). Involvement can be operationalized by the level of participation in clubs and societies, student government, campus employment, community service, residential activities, learning communities, and peer and faculty interactions. Student involvement is associated with greater than average changes in entering freshman characteristics (Astin, 1999). What's more, involvement is more strongly associated with change than either entering characteristics or institutional characteristics (Astin, 1999).

Mannan (2007), critiques Tinto's theory stating that is more applicable to developed countries like the United States where higher education institutions are equipped with resources and readily available to provide students with a wide range of opportunities such as the benefit of obtaining numerous academic and non-academic scholarships. For example, in the US students are highly involved in either social clubs or sports. Unfortunately, the same is not true for HEIs in developing countries such as Jamaica where institutions lack the resources to support students' need and success.

Astin's theory argues that students perform better and are more likely to remain in college due to their involvement. However, others may argue that, in the context of the Caribbean, students are far less exposed as to how to navigate the academy. As a result of this, in the Caribbean, high retention rates among students are mostly due to institutional and socioeconomic challenges as opposed to their lack of involvement in the total campus experience. Therefore, faculty also play an integral role in students' success as students first interact within a classroom setting before getting involved in campus activities. The institution through faculty must implement measures where academic staff through students' interaction with the classroom and laboratories, are able to influence students' involvement and experience in higher education to support students' persistence.

\section{RESEARCH METHOD}

This study employed a longitudinal survey design over a five-year period. Three variables were used to reflect individual student characteristics. These were residential status: whether or not a student lives on campus; enrolment status: whether or not a student is enrolled full-time; and matriculation status: whether or not a student entered at the normal level. These individual characteristics were analysed with two outcome variables: degree grade point average (GPA) and time to degree. It is hypothesized that living on campus will redound to better academic performance because it allows more opportunity for interaction with peers and academics and access to educational resources. In the literature on student involvement and engagement, living on campus is positively related to retention (Astin, 1999; Tinto, 2004).

For the second characteristic, it is hypothesized that full-time students will exhibit better outcomes than part-time students based on the time devoted to studies. In the literature on student retention, part-time enrolment is associated with a reduced probability of persisting until graduation (Astin, 1999; Tinto, 2004). For the third characteristic, it is hypothesized that students who entered with normal qualifications will reflect better performance than students who entered 
with lower qualifications. Students who are academically underprepared are at higher risk of dropping out than are students who are academically prepared (Tinto, 2004).

These variables were analysed using dummy variable regression due to the inclusion of categorical variables. The independent variables are coded $1=$ on-campus, $0=$ off-campus; $1=$ fulltime, $0=$ part-time, and $1=$ normal entry, $0=$ lower entry. The continuous dependent variables are degree GPA and time to degree. Given the exploratory nature of the study, bivariate regression will precede multiple regression.

\section{About the Institution}

The University is a publicly funded, regional institution in the Caribbean with multiple campuses across various island-states. Within a United States context, this institution would be considered a predominantly minority-serving institution such as historically black colleges and universities (HBCU) given its large population of Black students. It has residential campuses in Jamaica, Barbados, and Trinidad and Tobago, and a virtual campus that provides online and distance education to the wider Caribbean. Collectively, the University enrols over 40,000 students per annum and graduates over 10,000 students each year. The University serves a predominantly Caribbean population. At the Jamaican campus, $90 \%$ of the student body are of Jamaican origin.

\section{Participants}

As part of a University-wide initiative, the office responsible for institutional planning and research on the Jamaican campus conducted a survey of first-degree students to assess the views and perceptions of those students about their experience at the Jamaican campus. The paper survey was administered in January 2010 to a cross section of classes by faculty/school. Of the total student population of 10,006 first-degree students, 2,129 participated in the survey reflecting a $21 \%$ response rate. The questionnaire has a total of seven sections that consisted of the following:

- Section I includes demographic information

- Section II inquired about student administrative services such as the registration and examinations processes.

- Section III gathered information on academic support services

- Section IV collected information on non-academic student support services such as counselling and health services and entertainment and recreational facilities.

- Section V asked a series of questions related to the degree programme such as teaching and course quality and contribution to the development of desirable attributes.

- Section VI inquired about the overall experience and satisfaction of the student.

- Section VII, intended for final year students, asked about their postgraduate plans and Alumni relationships. 
The tables below show the distributions of respondents, according to year of study (Table 1), gender (Table 2) and faculty or school (Table 3).

The following hypotheses were proposed:

$\mathrm{H}_{1}$ : $\quad$ Residential students have higher GPAs and shorter time-to-degree than nonresidential students

$\mathrm{H}_{2}$ : $\quad$ Full-time students tend to have higher GPAs and shorter time-to-degree than part-time students based on the increased time devoted to studies

$\mathrm{H}_{3}$ : Students who enter higher education with normal qualifications will reflect better performance in their GPAs and shorter time-to-degree than students who entered with lower qualifications

Table 1. Sample and Student Population by Year of Study

\begin{tabular}{lcccc}
\hline Year of Study & Sample & \% & Population & \% \\
\hline Year 1 & 886 & 42 & 3,940 & 39 \\
Year 2 & 685 & 32 & 2,705 & 27 \\
Year 3 & 558 & 26 & 3,361 & 34 \\
Total & 2,129 & 100 & 10,006 & 100 \\
\hline
\end{tabular}

Table 2. Distribution of First Degree Respondents by Sex

\begin{tabular}{lcccc}
\hline Sex & Sample & \% & Population & $\%$ \\
\hline Male & 457 & 21 & 2996 & 30 \\
Female & 1,672 & 79 & 7,010 & 70 \\
Total & 2,129 & 100 & 10,006 & 100 \\
\hline
\end{tabular}

Table 3. Distribution of First Degree Respondents by Faculty/School

\begin{tabular}{lcccc}
\hline Faculty/School & Sample & \% & Population & \% \\
\hline Humanities \& Education & 339 & 15.9 & 2,020 & 20 \\
Law & 54 & 2.5 & 191 & 2 \\
Medical Sciences & 481 & 22.6 & 1,422 & 14 \\
Pure \& Applied Sciences* & 364 & 17.1 & 2,107 & 21 \\
Social Sciences & 891 & 41.9 & 4,266 & 43 \\
Total & 2,129 & 100 & 10,006 & 100
\end{tabular}

Note. * Faculty name changed to Science and Technology as of 2012. However, data in the table was collected in 2010 


\section{RESULTS}

\section{Student Retention at the Jamaican Campus}

First-year retention rates have generally been high at the Jamaican campus. Despite some variation in recent years, the rate has remained at over 80\% for cohorts entering in 2009 to 2014 (Figure 1).

\section{First Year Retention Rate of First Degree Entrants}

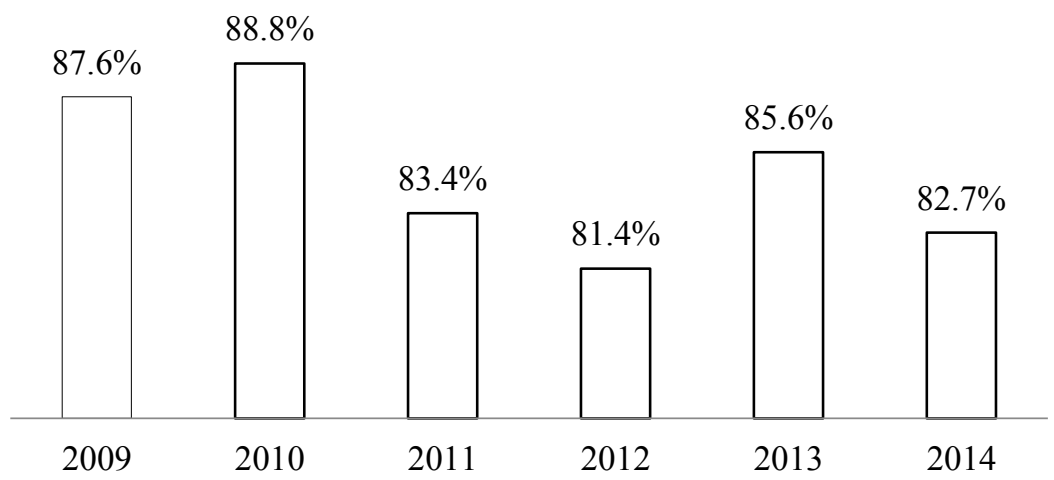

Figure 1. Retention rates of first-year students from 2009 to 2014.

The graduation rate is also relatively good for first-degree entrants (see Table 4). Over $70 \%$ of students in the Medical Sciences graduate on time compared to $30 \%$ in Science and Technology. The graduation rate vastly improves, however, to over $70 \%$ two years beyond the expected completion time for almost all programmes. The graduation rate increases to $56 \%$ in Science and Technology two years beyond the expected completion time. In the survey data used for this study, linked records were created for 2,046 students representing $20 \%$ of the undergraduate student population. As at December 2015, 89\% of the student respondents have graduated, while $11 \%$ have not.

Table 4. On-Time Graduation Rates by Program

\section{Faculty/School}

Humanities (B.A.) 3 yrs.

Education (B.Ed.) 2-3 yrs.

Medical Sciences (B.Sc. BBMS/Nursing) 3 yrs.

Medical Sciences (MBBS) 5 yrs.

Science \& Technology (B.Sc.) 3-4 yrs.

Social Sciences (B.Sc.) 3 yrs.
2006-07 2007-08

Entrants Entrants Entrants

$\begin{array}{lll}43.4 & 41.1 & 42.9 \\ 84.8 & 87.9 & 78.9 \\ 81.8 & 74.5 & 74.9 \\ 73.8 & 82.5 & 87.3 \\ 34.3 & 32.8 & 28.0 \\ 38.1 & 44.4 & 46.8\end{array}$




\section{Faculty/School}

2006-07 2007-08 2008-09

Entrants Entrants Entrants

\begin{tabular}{llll}
\hline Average All Programs & 42.9 & 43.1 & 42.5
\end{tabular}

Among those who have not graduated, $41 \%$ constitute dropouts who have not enrolled for two or more years. A next sizeable group represents non-returning students who have been absent for less than two years (13\%) but whose status is unknown. A further $12 \%$ of students represent transfers, while $10 \%$ represent academic dismissals. Of the remaining students, $15 \%$ are continuing their studies, $6 \%$ are on leave and $2 \%$ have withdrawn voluntarily. Based on institutional studies of non-returning students at the Jamaican Campus (Office of Planning and Institutional Research 2011), key reasons for students interrupting their studies are related to finances, academic preparation, and programme offerings. These factors suggest that institutional practices can influence student outcomes. To the extent that scholarships, academic advising, and programme diversity are priority areas of the University, then these can help mitigate the occurrence of student departure.

\section{Individual Characteristics on Degree GPA and Time to Degree}

Turning to the hypotheses on individual student characteristics on graduation rates, analyses were undertaken to test the hypotheses that full-time students, residential students, and normal entry students are likely to record higher degree GPAs and shorter time to degree than are part-time students, non-residential students, and lower entry students.

The first step in the analysis involved the examination of the variables to meet assumptions. Both the continuous dependent variables were bell shaped but showed some skew towards extreme values. In the time to degree variable, the range covered nine months up to eleven years, while the grade point averages ranged from .95 to 4.13 . The GPA scheme was revised in 2014-15 to reflect a minimum score of 2.00 for a pass degree instead of a 1.00 under the earlier scheme. The time to degree has a wide range because incoming transfer students may enter with advanced standing requiring little time to complete their programme and part-time students take longer to complete their degrees. Another observation in the data concerned the categories of the independent variables. There were uneven distributions between full-time (93\%) and part-time (7\%) students, residential (29\%) and non-residential (71\%) students, and normal entry $(66 \%)$ and lower entry $(33 \%)$ students.

The variables were then tested to meet the assumptions of an independent-samples $t$-test. The first three criteria were satisfied by having a continuous dependent variable, a dichotomous independent variable, and unrelated observations. The remaining requirements for normality, homogeneity of variance, and zero outliers were assessed. Outliers presented a problem in some of the tests. Even when data were transformed to address positive and negative skew, outliers were still present in some of the outputs. Rather than remove the outliers, which were not data entry errors, a decision was made to conduct the regression analysis for exploratory purposes, and to conduct a Mann-Whitney $U$ test, which is the non-parametric equivalent of an independent-samples $t$-test. The results of the bivariate regression analyses are presented in Table 5 .

It was also hypothesized that residential students would perform better than nonresidential students. Residential students exhibited superior performance to non-residential students in the GPAs and shorter time to degree. While the difference was not statistically 
significant in the GPA scores, it was significant in the time-to-degree by approximately two months.

The third hypothesis was also confirmed as it relates to students who entered the University with normal qualifications. Students with normal qualifications had higher GPAs and shorter time to degree than students with lower qualifications. The difference was not statistically significant for the GPA scores, but it was significant for the time to degree by one month.

Table 5. Unstandardized Regression Coefficients for Bivariate Regression

\begin{tabular}{lcc}
\hline Model 1 (n=1,829) & Status and Degree GPA & Sig. \\
\hline Constant (Part-time) & 2.663 & .000 \\
Full-time & .205 & $.001^{*}$ \\
& & \\
Model 2 (n=1,829) & Status and Time to Degree & \\
& 4.995 & .000 \\
Constant (Part-time) & -1.627 & $.000^{*}$ \\
Full-time & Residential Status and & \\
Model 3 (n=1,829) & Degree GPA & \\
& 2.843 & .000 \\
Constant (Non-Residential) & .049 & .113 \\
On Campus & Residential Status and Time \\
& to Degree \\
Model 4 (n=1,829) & 3.507 & \\
& -.166 & .000 \\
Constant (Non-Residential) & $.001^{*}$ \\
On Campus & Entry Status and Degree & \\
Model 5 (n=1,821) & GPA & \\
Constant (Lower Entry) & 2.851 & .000 \\
Normal Entry & .014 & .626 \\
Model 6 (n=1,821) & Degree \\
Constant (Lower Entry) & 3.525 & .000 \\
Normal Entry & -.113 & \\
& & \\
\hline
\end{tabular}

Note. *statistically significant $\mathrm{p}<.05$

When multiple regression was performed to see the combined effect of the independent variables on the dependent variables, we see more clearly the hypothesized relationships in Table 6. The average GPA for part-time, non-residential, and lower entry students combined is 2.698 . The coefficients are all positive for full-time, residential and normal entry students suggesting 
that any one of these characteristics will result in an increase in the GPA. Only full-time status, however, shows a statistically significant increase on the GPA.

Table 6. Unstandardized Regression Coefficients for Multiple Regression.

\begin{tabular}{lcc}
\hline Model $\mathbf{1}(\mathbf{n = 1 , 8 2 1})$ & $\begin{array}{c}\text { Independent Variables and } \\
\text { Degree GPA }\end{array}$ & Sig. \\
\hline Constant (Part-time, Non-Residential, Lower Entry) & 2.698 & .000 \\
Full-time & .158 & $.011^{*}$ \\
On Campus & .037 & .235 \\
Normal Entry & .004 & .893
\end{tabular}

Model $2(\mathrm{n}=1,821)$

Constant (Part-time, Non-Residential, Lower Entry)

Full-time

On Campus

Normal Entry
Independent Variables and

Time to Degree 4.957

$-1.552$

$.000^{*}$

$-.060$

.182

$-.032$

Note. ${ }^{*}$ statistically significant $\mathrm{p}<.05$

For time to degree, the combined average for part-time, non-residential and lower entry students was 4.957 years. The coefficients are all negative for full-time, residential and normal entry students suggesting a decrease in the time to degree. The decrease is statistically significant for full-time status only by 1.5 years.

Based on the regression analyses, it appears that individual student characteristics are determinants of performance. A student is more likely to graduate with a higher GPA and shorter time to degree by studying full-time than living on campus or entering the University with normal qualifications. Further, the combined characteristics of full-time study, living on campus and normal entry are more likely to result in higher GPAs and shorter time to degree than the combined characteristics of part-time study, living off campus and lower entry qualifications.

Given some of the limitations of the variables in meeting the criteria for parametric analyses, the variables were also subjected to a Mann-Whitney U test, the non-parametric equivalent of an Independent-samples T-Test.

The assumptions of a Mann-Whitney $U$ test are a continuous or ordinal dependent variable, a dichotomous independent variable, unrelated observations, and a similar or dissimilar shape in the distributions of the dichotomous independent variable. Where the distributions of the dichotomous independent variable are similar, the median scores can be compared. When the distributions of the dichotomous independent variable are not similar in shape, the mean ranks are compared.

The Mann-Whitney U test can provide important information on the median values of the independent variables and whether the median values are statistically significant. However, the Mann-Whitney U test is less powerful at explaining the differences between groups when mean 
ranks are compared. As a result, the hypotheses of this study may not be definitively confirmed by the Mann-Whitney U test in all cases. The results of the Mann-Whitney U test are presented in Table 7.

Table 7. Results of Mann-Whitney U test

\begin{tabular}{lcccc}
\hline $\begin{array}{l}\text { Dichotomous } \\
\text { variables }\end{array}$ & Mean rank & $\begin{array}{c}\text { Mann- } \\
\text { Whitney U }\end{array}$ & $\begin{array}{c}\text { Standardized test } \\
\text { statistic Z }\end{array}$ & $\begin{array}{c}\text { Asymptotic sig. } \\
\text { (2 sided) }\end{array}$ \\
\hline $\begin{array}{l}\text { Degree GPA } \\
\text { Full-Time }\end{array}$ & 924.98 & 73,383 & -3.13 & $.002^{*}$ \\
Part-time & 758.10 & & & \\
Live on campus & 949.58 & 321,793 & -1.73 & .083 \\
Live off campus & 902.08 & & & \\
Normal entry & 913.41 & 367,345 & -.22 & .827 \\
Lower entry & 907.70 & & & \\
Time to Degree & & & & \\
Full-time & 880.48 & 150,190 & 12.06 & $.000^{*}$ \\
Part-time & 1496.63 & & & \\
& & & & \\
Live on campus & 841.03 & 377,910 & 3.95 & $.000^{*}$ \\
Live off campus & 944.82 & & & $.000^{*}$ \\
Normal entry & 849.94 & 444,267 & 7.36 & \\
Lower entry & $1,033.81$ & & &
\end{tabular}

Note. * statistically significant $p<.05$

Examination of the distributions of the independents variables confirmed that the distributions were dissimilar in shape except in the case of residence and time to degree. As a result, the findings are presented and discussed in terms of the mean ranks. Although we are unable to confirm the hypothesis that full-time students have a higher GPA and shorter time to degree than part-time students, the mean ranks in both cases are significantly different. As for students living on campus, the data do not confirm their superior performance to non-residential students. Rather, there is a statistically significant difference in the mean ranks of students who live on and off campus by time to degree. Similarly, the data do not confirm that normal entry students performed better than lower entry students. Rather, there is a statistically significant difference in the mean ranks by time to degree. Of interest is that these results are similar to the results in the regression analyses. In both outputs, group differences are statistically significant for time to degree and less so for degree GPA. 


\section{Limitations of the Study}

The survey instrument, designed to measure student satisfaction may not have been useful for testing a theory of academic and social integration. It would be useful, however, to consider the theory of academic and social integration when planning future surveys. The instrument would also need to collect individual student characteristics related to social status and the goals and objectives for attending university. In this way, the outcomes of students can be better understood in terms of their intentions and objectives.

\section{DISCUSSION AND CONCLUSIONS}

This study examined student retention and graduation rates at the Jamaican campus of a Caribbean regional university by using cohort data from the Student Records database as well as linked data from a Student Experience Survey. The cohort data from the Student Records database show retention rates at over $80 \%$ from 2009-2014. Among non-returning students, many disrupt their studies for reasons related to finances, academic preparation, and programme offerings. These factors suggest that institutional practices can influence student outcomes. To the extent that scholarships, academic advising, and programme diversity are priority areas of the University, then these can help mitigate the occurrence of student departure. Indeed, scholarships are offered through the various Faculties and the Office of Student Financing. Also, at the Jamaican campus, students who reside within the institution's township, inner-city communities and have been accepted by the institution are provided with the opportunity to apply for scholarships funded through the university. Nevertheless, despite the provision of grants and scholarships, the gap continues to widen as many students still face difficulties of securing funding for their tuition as only a limited number of scholarships are made available to students. In agreeing with Jamelske (2009), "the higher an institution's retention rate [and graduation rate] is, the more competitive they will be in recruiting top students" (p. 374). As such institutions would need to affect long term changes in bridging this gap.

Individual student characteristics were then analysed to predict student outcomes. It was hypothesized that full-time students, residential students, and normal entry students would have higher degree GPAs and shorter time to degree than part-time students, non-residential students and lower entry students. The findings reflect that full-time status is the strongest predictor of degree GPA and time-to-degree, and the combined variables of full-time status, residential status and normal entry status are better predictors of degree GPA and time-to-degree than are parttime status, non-residential status and lower entry status in the regression analyses. The data pointed out that given the significant variables, students were unable to complete their programmes within the given 3-year marker normally required of the institution, which calls into question the need to revisit the popular 3-year timeline for completion of most programmes at the institution.

In looking at ways to improve full time status and residential access at the Caribbean regional university, we need to examine various models of access, retention and student involvement. Paterson and Stewart (2016) examining Astin's (2012) input-environment-output model found that older female students at the time of entry with higher number of courses passed in high school had a higher probability of being retained in university.

Following the results of this study, implications for institutional action can look at a threepronged approach to increase access and better retain and graduate students. Referring to Figure 2 below, the first phase would be the Pre-First Year Academic and Social Participation. This 
phase would include the development of transition or 'bridge' programmes between outgoing high school students and incoming university students. Students would take part in summer university transition programmes during the summer before their first-year in which they can live on campus and engage in the daily routine and expectations of university life. An enrolment management team would be developed to create sustainable measures for increasing access to the university. In doing this, academic advising and selection of best-fit courses would better transition students into the university. Financial support, counselling and programming will be a critical component of this stage as it is a leading factor to students' dropout rates and part-time status enrolment.

The second phase would include a First Year Course-Credit Programme in which students take first year courses for credit that is geared to socialize and better transition students to life as a university student. This would include academic and writing expectations, financial and budget management skills, and developing critical reading and thinking skills to name a few. Quarterly interventions by academic advisors would be mandatory for students below the pass rate and struggling in courses. Increased free tutoring offerings will be embedded as a part of the academic advising unit's portfolio and offered to all first-year students.

The last stage is envisioned as a living and learning community that is customized to suit the needs of both part-time and full-time students as well as residential and non-residential. These programmes will be designed around majors first and for those undecided, students will be assessed to align with their career goals. This programme would be aimed at developing peermentors and peer-led tutorials and provide programme workshops and training throughout the year to better support students.

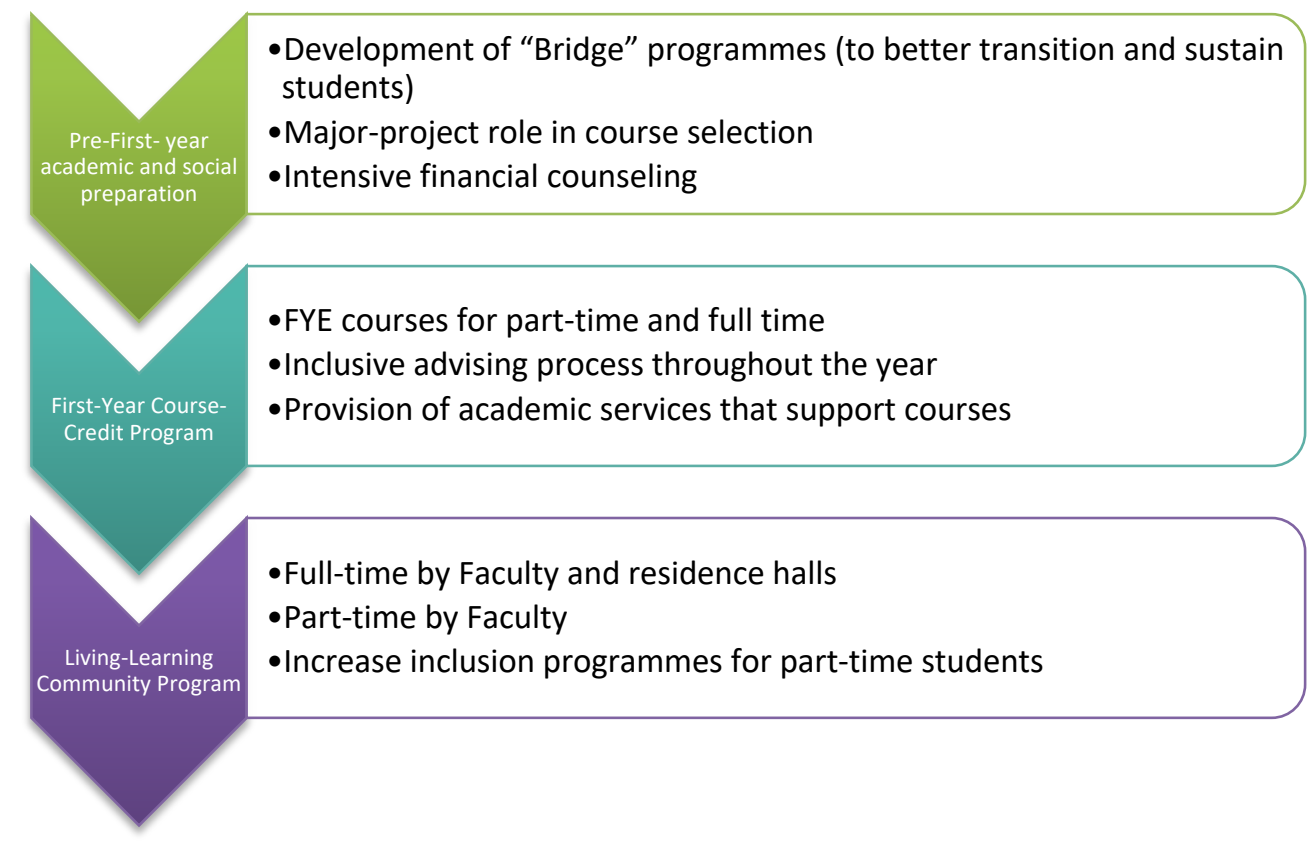

Figure 2. Conceptual Model for Institutional Action

To close, the role of higher education in the Caribbean is critical to not only economic growth but also sustainability and societal resilience. To build and develop a nation, a country 
must develop its people in the form of a knowledge economy. As such, access, retention, persistence and graduation of students in higher education are of national concern. Zaheer, Gul, Wazir and Wazir (2016) articulate that it is vital that students graduate to guarantee a healthy economy. They stated that "it is empirically proven that those who have graduate degree can find a job and hold on more easily as compared to their non-graduate counterparts" (Richard \& Parker, 2012 as cited in Zaheer et al, 2016, p. 37).

According to Brunsden, Davies, Shevlin and Bracken (2000) if universities look from a positive lens, dropouts will not be viewed based on Durkheim's suicidal analogy, but, instead a student dropping out could be viewed as a student who has exited the university and entered the new social world like the world of work. In this case, the student is not bounded by the walls of the university as they are individuals who make their own decisions sometimes based on personal reasons. Higher educational institutions, like the UWI could also implement measures not only to support institutional action but to also look at students' attrition at the individual level that is analysing each student's case as to why they have fallen behind or chosen to exit the system. Hence the importance of taking decisive action that introduces more practical solutions to students in assisting with to bridging the gap between access and persistence is critical to the graduation of students. Implications for sustainability measures and future research on this topic in the Caribbean are paramount for the development of the region.

\section{REFERENCES}

Astin, A. (2012). Assessment for excellence: The philosophy and practice of assessment and evaluation in higher education (2nd ed.). New York: Rowman \& Littlefield Publishers, Inc.

Bastick, T. (2002). Gender discrimination in education and employment: The marginalized men and wasted women of Dominica. In T. Bastick and A. Ezenne (Eds.), Sociology of education: Research in the Caribbean, (pp. 33-56). Kingston, Jamaica: Educational Research Centre, University of the West Indies.

Black, D. A. (2015). Internationalization, cross-border tertiary education and the challenge for quality: A Jamaican perspective. In A. K. Perkin (Ed.), Quality in higher education in the Caribbean, (pp. 171-180). Kingston, Jamaica: The University of the West Indies Press.

Braxton, J., Milem, J., \& Sullivan, A. (2000). The Influence of Active Learning on the College Student Departure Process: Toward a Revision of Tinto's Theory. The Journal of Higher Education, 71(5), 569-590. doi:10.2307/2649260

Brunsden, V., Davies, M., Shevlin, M., \& Bracken, M. (2000). Why do HE Students Drop Out? A test of Tinto's model. Journal of Further and Higher Education, 24(3), 301-310. doi: $10.1080 / 030987700750022244$

Chipman-Johnson, R., \& Vanderpool, J. (2003). Gender participation in higher education within the Anglophone Caribbean. Caracas, Venezuela: International Institute for Higher Education in Latin America and the Caribbean.

Davies, O. (2005). Financing higher education: The government perspective. In R. Holding \& O. Burke (Eds.), Revisiting tertiary education policy in Jamaica: Towards personal gain or public good? (pp. 119-126). Kingston, Jamaica: Ian Randle Publishers.

Down, L. (2010). Teaching and learning in, with and for community: Towards a pedagogy for education for sustainable development. Southern African Journal of Environmental Education, 27, 58-70.

Edwards-Henry, A. M. (2015). Improving learning through effective teaching. In A. K. Perkins (Ed.), Quality in higher education in the Caribbean (pp. 21-33). Kingston, Jamaica: The University of the West Indies Press.

Gale, T., \& Parker, S. (2014). Navigating student transition in higher education: Induction, development, becoming. In Brook H., Fergie D., Maeorg M., \& Michell D. (Eds.), Universities in transition: 
Foregrounding social contexts of knowledge in the first-year experience (pp. 13-40). South Australia: University of Adelaide Press. Retrieved from http://www.jstor.org/stable/ 10.20851/j.ctt1 1304 xh.5

Gift, S. (2015). The University of the West Indies: Moving quality to the next level. In A. K. Perkins (Ed.), Quality in higher education in the Caribbean (pp. 21-33). Kingston, Jamaica: The University of the West Indies Press.

Gift, S., Moniquette, J., \& Perkins, A. (2010). Quality assurance at the University of the West Indies. Journal of Education and Development in the Caribbean, 12(1), 91-114.

Grant-Woodham, J. (2007). Accessing higher education: Transitions within an era of change. In K. O. Hall \& R. M. Cameron (Eds.), Higher education: Caribbean perspectives (pp. 132-165). Kingston, Jamaica: Ian Randle Publishers.

Hamilton, M., \& Severin, F. (2005). Implementing the mission: Improving access. Challenges for tertiary education in Jamaica. In R. Holding \& O. Burke (Eds.), Revisiting tertiary education policy in Jamaica: Towards personal gain or public good? (pp. 31-45). Kingston, Jamaica: Ian Randle Publishers.

Hutton, D. M. (2009). Preparing the workforce for the 21 st century: The Jamaican experience. Caribbean Journal of Education, 31(1), 21-45.

Hutton, D. M. (2010). Funding options and strategies: Deriving a model for higher education in Jamaica and other developing countries. Journal of Education and Development in the Caribbean, 12, 5378.

Jamelske, E. (2009). Measuring the impact of a university first-year experience program on student GPA and retention. Higher Education, 57(3), 373-391. Retrieved from http://www.jstor.org/stable/40269128

James, V., \& Williams, C. (2005). Financing higher education: Policy choices for Jamaica. In R. Holding \& O. Burke (Eds.), Revisiting tertiary education policy in Jamaica: Towards personal gain or public good? (pp. 148-210). Kingston, Jamaica: Ian Randle Publishers.

Leo-Rhynie, E. (2005). Diversity, liberalization and competition in tertiary and higher education: Implications for quality assurance. In R. Holding \& O. Burke (Eds.), Revisiting tertiary education policy in Jamaica: Towards personal gain or public good? (pp. 269-283). Kingston, Jamaica: Ian Randle Publishers.

Office of Planning and Institutional Research. (2011). First Year Student Retention Survey, Class of 200910. Office of Planning and Institutional Research. Retrieved from http://www.mona. uwi.edu/opair/managementreports/studiesandsurveys/First\%20Year\%20Student\%20Retention\% 20Survey,\%20Class\%20of\%202009-10.pdf

Mannan, M. (2007). Student attrition and academic and social integration: Application of Tinto's model at the University of Papua New Guinea.Higher Education, 53(2), 147-165. Retrieved from http://www.jstor.org/stable/29735048

Morris, H. A. (2009). Developing policies for technical and vocational education and training (TVET) in the Caribbean. Caribbean Journal of Education, 31(1), 1-20.

Paterson, N., \& Stewart, S. (2016). Predictors of student retention at the University of the West Indies, Mona Campus: Using Astin's I-E-O assessment model. Journal of Education and Development in the Caribbean, 15(1), 101-123.

Reddock, R. (2010). Gender and achievement in higher education. Journal of Education and Development in the Caribbean, 12(1), 1-21.

Roberts, V. (2007). Accreditation and evaluation systems in the English-Speaking Caribbean. In K. O. Hall \& R. M. Cameron (Eds.), Higher education: Caribbean perspectives (pp. 45-94). Kingston, Jamaica: Ian Randle Publishers.

Rosalie Robinson. (2004). Pathways to completion: Patterns of progression through a university degree. Higher Education, 47(1), 1-20. Retrieved from http://www.jstor.org/stable/4151554

Rovai, A. (2003). In search of higher persistence rates in distance education online programs. Internet and Higher Education, 6 (1), 1-16. 
Shaw, A. (2005). Financing higher education: The opposition perspective. In R. Holding \& O. Burke (Eds.), Revisiting tertiary education policy in Jamaica: Towards personal gain or public good? (pp. 127-132). Kingston, Jamaica: Ian Randle Publishers.

Stewart, S. (2015). Schooling and coloniality: Conditions underlying 'extra lessons' in Jamaica. Postcolonial Directions in Education. 4(1), 25-52.

Tinto, V. (1975). Dropout from higher education: A theoretical synthesis of recent research. Review of Educational Research, 45(1), 89-125.

Tinto, V. (1999). Taking retention seriously: Rethinking the first year of college. NACADA Journal, 19(2), $5-9$.

Tinto, V. (2004). Student retention and graduation: Facing the truth, living with the consequences. Washington, DC: The Pell Institute for the Study of Opportunity in Higher Education.

Tinto, V. (2006). Research and practice of student retention: What next? Journal of College Student Retention, 8(1), 1-19.

Tinto, V. (2013). Linking learning and leaving: Exploring the role of the college classroom in student departure. Retrieved from https:/vtinto.expressions.syr.edu/wp-content/uploads/2013/01/ Linking-Learning-and-Leaving.pdf

Tinto, V., \& Cullen, J. (1973). Dropout in higher education: A review and theoretical synthesis of recent research. Washington, DC: Office of Planning, Budgeting, and Evaluation of the U.S. Office of Education.

Walsh, A. (1990). Statistics for the social sciences: With computer applications. New York: Harper \& Row, Publishers, Inc.

Wint, A. (2010). Internationalization of tertiary education in the Caribbean. Caribbean Journal of Education, 32(2), 259-284.

Zaheer, Z., Gul, S., Wazir, I., \& Wazir, S. (2016). Determinants of student dropouts: A case study of business students. Business and Economic Review, 8(SE): 37-52. doi: 10.22547/BER/8.SE.3

SARAN STEWART, PhD, Saran Stewart, PhD, Senior Lecturer, Comparative Higher Education, Faculty of Humanities and Education, University of the West Indies, Jamaica.

NICOLA PATERSON, Office of Planning and Institutional Research, University of the West Indies, Mona Campus.

SHENHA YE FERGUSON, MA Graduate, Higher Educational Management, University of the West Indies, Mona Campus. Correspondence concerning this article should be addressed to Saran Stewart, School of Education, University of the West Indies, Mona Campus, Kingston 7, Jamaica.saran.stewart@uwimona.edu.jm. 